\title{
Jørn Loftager
}

\section{Aktivering som (ny) velfærdspolitisk trejdevej}

Med 1990'ernes aktiveringslinje er også dansk velfærdspolitik drejet ind på den tredje vej. På centrale punkter markerer det et brud i forhold til den tidligere tredje vej, som den lader sig rekonstruere på grundlag af Marshalls vision om et lige medborgerskab (citizenship) og Durkheims forestilling om en moderne, organisk form for solidaritet. Færllesskabet tankes ikke længere liberalt som et politisk-socialt fællesskab baseret på universelle borgerrettigheder og -pligter, men kommunitaristisk som et værdi- og identitetsfællesskab, hvor den afg $\emptyset$ rende nøgle til inklusion er det at arbejde, henholdsvis det ikke at være "passivt" forsørget.

"The most meaningful stake anyone can have in society is the ability to earn a living and support a family" (Tony Blair)

For en umiddelbar betragtning synes den aktivlinje, der er slået igennem i 1990'ernes danske social- og arbejdsmarkedspolitik, at udgøre et ganske stærkt argument for "den tredje vej" som vejen frem. På den ene side er aktiveringspolitikken i god overensstemmelse med den tredje vejs tænkning. Hovedprincippet om, at retten til modtagelse af en indkomst fra det offentlige skal være betinget af pligten til at levere en konkret modydelse i form af arbejde, uddannelse eller jobtræning, udgør et hovedelement $i$ den tredje vejs fokusering på den enkeltes pligter og ansvarlighed over for fællesskabet. På den anden side er den danske aktiveringsstrategi for længst blevet erklæret en overvældende succes. Den har udgjort en hovedhjørnesten i bestræbelserne på at gøre Danmark til "foregangsland" blandt partnerne i EU og OECD, hvorfra reaktionerne da også har været meget positive. Danmark har fået høje karakterer for sin aktive arbejdsmarkedspolitik, og på linje hermed har forskere hæftet sig ved "Det danske mirakel" (Madsen, 1999; Torfing, 1999). Ikke blot er det lykkedes at reducere arbejdsløsheden dramatisk uden samtidig at skabe hverken inflation eller betalingsbalanceproblemer, en vigtig del af mirakelhistorien er også, at den generelle økonomiske fremgang ikke er blevet betalt med $\emptyset$ get ulighed og social disintegration.

Det er rimeligvis også i det lys, man må se den bemærkelsesværdige politiske konsensus, der er opstået med aktiveringslinjen. Mens især arbejdsmarkedspolitikken tidligere har udgjort et felt, hvor de klassiske, modstående ideologiske synspunkter mellem venstre og højre har kunnet profileres, er det nu blevet et område præget af grundlæggende enighed. 1990'ernes arbejdsmarkedsreformer blev gennemført af socialdemokratisk ledede regeringer, men med fuld og helhjertet tilslutning fra den borgerlige opposition. På venstrefløjen har SF og Enhedslisten i nogen grad været kritisk indstillede og stemt imod dele af aktiveringslovgivningen, men modstanden blev aldrig så alvorlig, at den fik konsekvenser for de to partiers rolle som parlamentariske garanter for de pågældende regeringer.

Ser man lidt nøjere efter, tager billedet af aktiveringspolitikken sig dog ikke så entydigt ud endda. Således er det omstridt hvor meget nyt, der egentlig er tale om, 
og om der derfor er grundlag for at sige, at den danske velfærdspolitik er slået ind på en ny (tredje) vej (Nørgaard, 1999; Green-Pedersen et al., 2(001). Dernæst, og nok så væsentligt, er der kun usikkert empirisk belæg for, at den konstaterede gunstige $\emptyset$ konomiske og sociale udvikling kan tilskrives aktiveringsindsatsen. Tidsmæssigt sammenfald er jo ikke ensbetydende med en årsag/virkningsrelation, og de foreliggende effektundersøgelser viser kun temmelig sparsomme positive virkninger i form af øget integration på arbejdsmarkedet (Abrahamson og Oorschot, 2002), ligesom der er sået alvorlig tvivl om gyldigheden af de antagelser og problembeskrivelser, aktiveringsstrategien bygger på (Albrekt Larsen, 2000, 2002; Goul Andersen, 2002).

Jeg skal i denne artikel argumentere for, at det faktisk giver god mening at opfatte aktiveringspolitikken som udtryk for en kvalitativ ændring, der repræsenterer et brud med den forudgående velfærdsmodel og dens logik. I den forbindelse skal det være en vigtig pointe, at det er misvisende at fremstille aktiveringens tredje vej som afløser for en fastlåst stillingskrig mellem en neoliberal første vej og en (beton)socialdemokratisk anden vej (eller omvendt) - hvilket dens fortalere og analytikere ofte kan efterlade indtrykket af. Nej, den nye tredje vej erstatter en allerede fungerende social-liberal tredje vej, og det er først på grundlag af dennes nærmere specificering, at det nye ved den nye tredje vej kan karakteriseres og vurderes nærmere. Når der i øvrigt kan være grund til at rette opmærksomheden mod den tidligere velfærdsmodel, skyldes det, at den ved nærmere eftersyn måske ikke falder så dårligt ud sammenlignet med aktiveringslinjen. Det skal i al fald være det overordnede synspunkt, jeg i det følgende skal søge at gøre gældende. Intentionen er dermed at problematisere "sejrherrens" historie om det danske mirakel ved at præsentere en alternativ tolkning af de altså to tredjeveje og deres egenskaber. Hovedsagen vil være at påpege, hvordan aktiveringspolitikken udfordrer nogle ellers alment hyldede idealer om lige medborgerskab og en bestemt form for samfundsmæssig solidaritet, som i betydelig grad knyttede sig til den tidligere velfærdsmodel.

Hvad dette nærmere drejer sig om, skal der redegøres relativt grundigt for i de to første afsnit, hvor den tidligere velfærdsmodel og dens logik skal søges rekonstrueret med reference til T.H. Marshalls klassiske teori om rettigheder og medborgerskab og Emile Durkheims teori om mekanisk og organisk solidaritet. Dermed skal gøres opmærksom på nogle i debatten næsten helt upåagtede liberale forestillinger om fællesskab og solidaritet, som synes velegnede til en kvalificerende perspektivering af den (nye) tredje vejs - kommunitaristisk prægede forestillingsverden. Dernæst følger en præsentation af nogle af aktiveringspolitikkens væsentligste elementer og principper, og i forlængelse heraf præciseres både, hvordan den stemmer overens med den aktuelle tredjevejs-tænkning, og hvordan den bryder med den tidligere velfærdsmodel.

I sidste afsnit sættes kortfattet spørgsmålstegn ved de præmisser af empirisk art, som aktiveringspolitikken bygger på. Sammen med den forudgående normative problematisering efterlader dette naturligvis et stort spørgsmål om forklaringen på denne politiks sejrsgang. Et muligt bud på en sådan (del)forklaring drøftes afslutningsvis. 


\section{Lige medborgerskab og organisk solidaritet: den "gamle" tredjevej}

Når jeg skal argumentere for, at der med aktiveringspolitikken er etableret et nyt paradigme, hænger det sammen med en bestemt beskrivelse af den tidligere velfærdsmodel og de udviklingstendenser, der prægede den. Og som sagt skal denne beskrivelse referere teoretisk til Marshalls rettighedsteori og Durkheims teori om social arbejdsdeling og solidaritet. Sigtet er at påpege, hvordan den danske model i høj grad kan siges at have virkeliggjort Marshalls ideal om et lige medborgerskab og det, Durkheim betegnede som organisk solidaritet.

T.H. Marshalls for længst klassiske essay fra 1950 Citizenship and Social Class har en typisk tredjevejskarakter, idet det som hovedtema har formidlingen mellem et lige medborgerskab og et socialt system præget af klasseulighed, eller, kort og generelt sagt, mellem demokrati og kapitalisme (Marshall, 1950, 1966). Marshalls teori er ofte og med rette blevet kædet sammen med den universelle velfærdsstat, som den specielt er udviklet i de nordiske lande, og svarende til den gængse omtale af denne model som "socialdemokratisk" er samme betegnelse hæftet på Marshalls teori om rettigheder og medborgerskab (Esping-Andersen, 1990; Ho og Jørgensen, 1999; Goul Andersen, 2002). Mere korrekt er det dog at placere Marshall inden for den social-liberale tradition (Turner, 1993), hvilket naturligt kan lede til overvejelser, om ikke også det er tvivlsomt at se den universelle velfærdsstat som et socialdemokratisk projekt par excellence. Ganske vist er Socialdemokratiet historisk blevet identificeret med velfærdsstaten, og partiet har også åbenlyst spillet en central politisk rolle i forbindelse med dens opbygning; men for det første har de borgerlige partier faktisk haft en væsentlig del af ansvaret for fastlæggelsen af de spor, ad hvilke den danske velfærdsstat har udviklet sig (Nørgaard, 2000). For det andet må den universalisme, som så stærkt har præget det danske velfærdssystem, grundlæggende siges at tilhøre en liberal tankeverden, hvorfor det heller ikke er overraskende, at aktuel kritik af universelle velfærdsordninger i lige så høj grad formuleres fra venstre som højre side af det politiske spektrum (jf. Olsen et al., 2002).

Netop den universalisme, som er indeholdt i rollen som borger og de almene rettigheder og pligter, der definerer den, er afgørende for Marshall. Det centrale budskab er, at klasseuligheden afgørende kan imødegås gennem etablering af en lige status som borgere (citizens) (1966: 6). Historisk udfoldes medborgerskabet med realiseringen af tre successive typer af rettigheder. Først de civile rettigheder, der bryder igennem i det 18 . århundrede. De omfatter de borgerlige frihedsrettigheder og konstituerer retsstaten med dens grundprincip om lighed for loven. Formelt og delvist reelt betyder det et radikalt brud med det feudale standssamfund; som Marshall bemærker: "No subtle argument is needed to show that citizenship is incompatible with medieval feudalism" (1966: 6). Derimod var disse lige rettigheder ikke uforenelige med det kapitalistiske samfunds uligheder, men tværtimod en forudsætning herfor. På grundlag af blandt andet ejendomsret og næringsfrihed åbnedes op for en $\emptyset$ konomisk udvikling med massiv ulighed til følge. Ejendomsret var og er ikke ensbetydende med en ret til at være i besiddelse af ejendom, men til at erhverve og beskytte den, hvis man kan (1966: 21). Tilsvarende blev de fattiges fordringer på hjælp i henhold til the poor law ikke betragtet som del af borgerens 
rettigheder, men som alternativ hertil i den forstand, at modtagelse af hjælp var ensbetydende med at give afkald på rollen som borger (Marshall, 1966: 15).

Det andet sæt rettigheder, der definerer medborgerskabet, er de politiske og herunder først og fremmest den almindelige valgret, som udvikles i løbet af det 19., og fuldendes i begyndelsen af det 20. århundrede. Ligesom de civile var også de politiske borgerrettigheder i første omgang reelt forbeholdt borgerskabet. Nok var og måtte rettighederne være universelt formulerede, og alle (mænd) havde da også formelt mulighed for at opfylde deltagelseskravene om formue- og ejendomsbesiddelse. Men reelt udelukkede klasseuligheden langt de fleste fra at realisere de politiske rettigheder. For Englands vedkommende var det først med "The Act of 1918", at grundlaget for de politiske rettigheder skiftede "from economic substance to personal status" (1966: 15).

Imidlertid er det først med de sociale rettigheder i det 20. århundrede, at de civile såvel som de politiske rettigheder og dermed et begyndende lige medborgerskab for alvor kan virkeliggøres. I forhold til 1800 -tallets fattigdomslovgivning er det fundamentalt nye, at disse rettigheder får status af universelle borgerrettigheder: "... social rights imply an absolute right to a certain standard of civilisation which is conditional only of the discharge of the general duties of citizenship. Their content does not depend on the economic value of the individual claimant ... thus creating a universal right to an income which is not proportionate to the market value of the claimant" (1966: 26, 28).

Dermed introduceres et nyt ideal, der ikke blot går ud på at hæve niveauet for de nederste lag, men, som det metaforisk siges, at lave hele bygningen om - fra en skyskraber til en bungalow. Der sker et skifte fra et defensivt syn på velfærdssystemet som sikkerhedsnet til et offensivt ideal om sikring af et reelt lige medborgerskab. Den samme universalisme, som jo er et konstitutivt træk ved den liberal-demokratiske retsstat, skal også være det for staten som velfærdsstat. Udvidelsen af de sociale rettigheder - til uddannelse, sundhed, social sikring osv. - er tilsvarende ikke primært et middel til indkomstudjævning. "What matters is that there is a general enrichment of the concrete substance of civilised life ... Equalisation is not so much between classes as between individuals within a population which is now treated for this purpose as though it were one class. Equality of status is more important than equality of income" (1966: 33).

Selv om Marshall klart koncentrerer sig om rettighederne, indgår også pligtsiden i form af blandt andet skattepligt, væmepligt, undervisningspligt, ligesom pligten til at arbejde siges at være af "paramount importance" (1966: 45). Men forestillingen er ikke den, at pligterne tegner fællesskabet, og rettighederne individualiteten. Rettighederne skaber nemlig selv i kraft af deres universelle karakter samfundsmæssig integration og solidaritet, og det er derved, at fællesskabsforestillingen kan betegnes som distinkt liberal. De universelle rettigheder er udtryk for ligeværdige borgeres gensidige anerkendelse i det politiske fællesskab, som medborgerskabet (citizenship) betegner, og som både adskiller sig fra førmoderne fællesskaber baseret på slægtskab og fra national-patriotiske, følelsesbetonede fællesskaber. Den sociale integration "spread from the sphere of sentiment and patriotism into that of material enjoyment" (1966: 26). 
Imidlertid er det med hensyn til spørgsmålet om integration og solidaritet værd at inddrage en anden klassisk sociologisk teori, nemlig Durkheims teori om solidaritet. Teorien er indeholdt i hovedværket Om den sociale arbejdsdeling fra 1893, der indeholder Durkheims bud på en analyse af overgangen fra det traditionelle til det moderne samfund og de dermed forbundne rystelser af den sociale orden (Durkheim, 1893/2000). I betragtning af, at det for længst er blevet almindeligt at tale om det moderne industrisamfunds gennemgribende omdannelse, kan det eventuelt forekomme mærkværdigt at gøre brug af en teori, der altså handler om dette samfunds gennembrud. Imidlertid forekommer den at være mere aktuel end nogensinde, hvilket så i øvrigt kan begrunde en vis skepsis over for alle tidens påstande om en helt ny epoke i verdenshistorien.

Durkheim skelner mellem to former for samfundsmæssig solidaritet, en mekanisk og en organisk. Begge eksisterer i alle samfund til alle tider, men hvor det traditionelle samfund er domineret af den mekaniske, erstattes denne i det moderne samfund mere og mere af den organiske solidaritet. Den mekaniske solidaritet er, siger Durkheim, en solidaritet ved lighed. Det vil sige, at den baserer sig på, at personeme deler værdier og i stor udstrækning identificerer sig med hinanden. Fordi man forstår sig selv og verden på samme måde, vil man yde assistance, når den anden har behov derfor. Dermed bekræfter og understøtter man nemlig de værdier og den livsforn, man selv deler. Betegnelsen mekanisk skyldes, at solidariteten ydes instinktivt og indebærer et følelsesmæssigt engagement. Forholdet mellem individ og fællesskab udgør et nulsumspil, således at jo mere individualitet desto svagere fællesskab og vice versa (Durkheim, 2000: 139).

Heroverfor er den solidaritet, der opstår med det moderne samfund med fremskreden arbejdsdeling, en organisk solidaritet ved forskelle. I stedet for at basere sig på ensartede værdier, beror den på de funktionelle og anonyme afhængigheder, der opstår med den samfundsmæssige differentiering og arbejdsdeling. Det afg $\emptyset$ rende er ikke, om den anden deler ens egne normer og værdier, men om vedkommende varetager funktioner, som er væsentlige for, at jeg kan lykkes i mine funktioner. Det moderne menneske indser, at det indgår $i$ et organisk, differentieret hele, hvor den gensidige afhængighed vokser med forskellene, sådan at en styrkelse af det kollektive går hånd i hånd med vækst i individualitet.

\footnotetext{
"Her styrkes helhedens individualitet da samtidigt med delenes. Samfundet bliver bedre i stand til at bevæge sig samlet, samtidig med, at alle dets elementer har flere egenbevægelser. Denne solidaritet svarer til, hvad man ser hos højerestående dyr. Hvert organ har faktisk sit specielle fysiognomi, sin autonomi, og alligevel er organismens enhed så meget større, jo mere udpræget dette individuelle særpræg er. På grund af denne analogi foreslär vi, at man kalder den solidaritet organisk, som skyldes arbejdsdelingen" (Durkheim, 2000: 140).
}

Durkheim aflæser den relative betydning af de to former for solidaritet i retssystemets udvikling og straffenes ændrede funktion. I samfund domineret af mekanisk solidaritet er hovedformålet med straffen at beskytte de fælles værdier, og det sker ved at fordømme og forlange soning af enhver, der truer dem. Når forseelser, som ud fra et moderne synspunkt tager sig harmløse ud, ofte udløser eksorbitant hårde straffe, må det netop forstås som udslag af, at den afvigende adfærd 
udgør en trussel mod det værdibaserede og identitetsdannende fællesskab. Organisk solidariske samfund er derimod karakteriseret ved, at civilretlig regulering kommer til at fylde mere og mere. Reglemes typiske funktion er ikke at opretholde et værdifællesskab, men at regulere adfærden i det funktions- og arbejdsdelte samfund. Svarende hertil er deres overtrædelse som oftest ikke forbundet med stærk følelsesmæssig afstandtagen og forargelse, idet der ikke krænkes livsværdier og identiteter. Sanktioners typiske formål er ikke soning og hævn, men genoprettelse af en forstyrret tilstand i funktionssystemet.

Selv om solidariteten i takt med den fremadskridende arbejdsdeling vil baseres mindre og mindre på de fælles værdier og identiteter, vil en kollektiv bevidsthed fortsat være til stede, "men den (vil) mere og mere bestå i måder at tænke og føle på, der er meget generelle og ubestemte, og som lader pladsen stå åben for en stigende mangfoldighed af individuelle meningsforskelle" (Durkheim, 2000: 173). Der er dog en vigtig undtagelse fra den generelle tendens til, at fællesskabet som værdifællesskab bliver stadigt svagere. Og det er med hensyn til individet og dets autonomi og rettigheder. Den generelt voksende tolerance gælder ikke, når det drejer sig om adfærd, der truer eller udviser mangel på respekt for andres individualitet og personlige ukrænkelighed. Det er konfronteret med en sådan adfærd, at vi er tilbøjelige til at involvere os følelsesmæssigt, forarges og forlange straffe, som ud fra mere "rationelle" overvejelser kan virke umådeholdent strenge. "Der er rigtignok et sted, hvor den fælles bevidsthed er blevet styrket og præciseret, og det er der, hvor den vedrører individet. I takt med at alle de andre overbevisninger og praksiser antager en mindre og mindre religiøs karakter, bliver individet genstand for en slags religion. Vi har en kult omkring personens værdighed ..." (Durkheim, 2000: 173.). Det er netop på grund heraf, at Durkheim efter min mening må karakteriseres som en liberal snarere end konservativ tænker. Ganske vist udgør samfundet og dets udvikling den primære enhed, men i stedet for at spærre for en anerkendelse af de centrale liberale værdier omkring individet, sætter det ham i stand til at formulere en historisk forståelse og begrundelse for disse værdier, som forekommer nok så troværdig som liberalistisk teori af både utilitaristisk og naturretlig observans.

\section{Den tidligere danske tredje vej}

Vendes blikket så mod den danske velfærdsstat, skal det for en ordens skyld først slås fast, at den naturligvis ikke er konstrueret efter en på forhånd lagt plan i overensstemmelse med de skitserede tanker om medborgerskab og solidaritet. Men en ting er genese, noget andet er faktisk funktion, gyldighed og legitimitet, og det er med henblik herpå, at det skal hævdes, at såvel Marshalls som Durkheims teoretiske pointer kan siges at give et godt bud på "hemmeligheden" i velfærdssystemet som det - ofte politisk-pragmatisk begrundet - er vokset frem. Uden at det skal søges nærmere dokumenteret, synes således Marshalls teori om rettighedernes historisk fremadskridende udvikling at passe glimrende med det danske tilfælde (jf. Knudsen, 2001 ). Her skal det gælde de seneste årtier. Dog kan en passant nævnes, at hvad specielt angår forestillingen om det almene og universelle, kom den med materiel basis i gårdmandsklassen på et tidligt tidspunkt til at vægte relativt 
tungt i en dansk sammenhæng - vigtige stikord kunne være: "opinionsstyret enevælde", landboreformer, Grundtvig, folkeoplysning, andelsbevægelse mv. (Bjøm, 1998). Da valget i slutningen af 1900-tallet mellem en skattefinansieret og rettighedsbaseret velfærdsmodel og en bidragsfinansieret forsikringsmodel faldt på førstnævnte, var motiverne bag dog utvivlsomt lige så meget præget af kortsigtede $\varnothing$ konomiske interesser som langsigtede principielle og ideelle overvejelser. Betragtes mere specifikt spørgsmålet om modtagelse af offentlig forsørgelse, illustrerer nyere danske socialpolitisk historie udmærket, hvordan modtagelse af forsørgelse har udviklet sig fra - som fattighjælp - at være ensbetydende med fratagelse af borgerlige og politiske rettigheder til at blive givet som universelle rettigheder.

Siden begyndelsen af 1970'erne har det danske velfærdssystem bidraget til en praktisk "universalisering" i den forstand, at stort set hele den voksne befolkning har fået status som individuelle indkomstmodtagere. Dels medvirkede udbygningen af den offentlige servicesektor til, at erhvervsfrekvensen for kvinder voksede hurtigt og kom på niveau med mændenes. Dels bidrog udvidelsen af systemet af rettighedsbestemte indkomstoverførsler antageligt også til den udvidede arbejdsstyrke, og i hvert fald betød den, at stort set alle uden egen erhvervsindtægt blev garanteret en offentlig overførselsindkomst. I den forbindelse er det især vigtigt at hæfte sig ved, at forskellige uddannelses- og jobtilbudsordninger muliggjorde en i praksis tidsubegrænset forbliven i dagpengesystemet. Det såkaldte indkomsterstatningsprincip i det sociale system trak i samme retning ligesom efterlønnen, der med udvidelsen af arbejdsstyrken hurtigt blev en universel rettighed ikke blot $\mathrm{i}$ kraft af dens skattefinansiering, men også i kraft af dens udstrækning til flere og flere. Helt på linje hermed kan nævnes såvel overgangsydelsen, der for en tid muliggjorde en de facto pensionering for ledige personer over 50 år, samt de forskellige orlovsordninger. I den anden ende af aldersskalaen blev såvel børnecheck som SU gjort uafhængige af forældreindtægten, og alt $\mathrm{i}$ alt tegnede denne udvikling en kurs i retning af det ultimativt universelle velfærdssystem, nemlig en borgerindkomst, som alle har en ubetinget ret til qua det at være borger (Goul Andersen, 1996; Loftager, 1996).

I historisk perspektiv er det nærliggende at jævnføre den dermed sikrede $\emptyset$ konomiske uafhængighed for den enkelte borger med den ejendomsbesiddelse, som tidligere udgjorde betingelsen for realiseringen af de politiske og til dels også de civile rettigheder - og dermed den lige status som borger. Således tolket kan den danske udvikling siges at have bekræftet Marshalls historieskrivning, inklusive visionen om skabelsen af et lige medborgerskab i kraft af, specielt, sociale rettigheder givet som universelle borgerrettigheder. Ganske vist havde Marshall næppe forestillet sig en udvikling som den danske, hverken med hensyn til arbejdsstyrkens størrelse inklusive den kønsmæssige ligestilling eller med hensyn til den store andel på omkring 20 pct. af befolkningen i den erhvervsdygtige alder med indkomst i form af offentlig overførsel. Men ingen af delene bryder med det centrale i visionen. Hvad angår etableringen af selvstændigt fors $\emptyset$ rgelsesgrundlag for kvinder, behøver det ingen nærmere argumentation, og man kan for $\varnothing v$ vrigt anføre det som en væsentlig mangel hos Marshall, at han ikke i sin bestræbelse på at analysere det lige medborgerskabs forudsætninger inddrager spørgsmålet om kvinders 
(daværende) typiske forsørgelsesafhængighed af manden. Sværere kan det være at se, hvordan en situation med en stor del af befolkningen på offentlig forsørgelse kan harmonere med idealet om det lige medborgerskab. Principielt er det imidlertid uproblematisk, idet det afgørende som påpeget er, at det ikke skal være en persons markedsværdi, der skal bestemme vedkommendes status som borger. Noget andet er så, om offentlig forsørgelse i praksis betyder marginalisering og eksklusion. At det er tilfældet har været et hovedsynspunkt i den danske velfærdsdiskussion i almindelighed og i begrundelserne for aktiveringslinjen i særdeleshed, men som det nedenfor skal fremgå, er det en opfattelse af tvivlsom gyldighed. I den forbindelse skal også peges på, hvordan den sammenhængskraft, der øjensynligt har præget det danske samfund, lader sig forstå $\mathrm{i}$ henhold til Durkheims begreb om organisk solidaritet. I forhold til Durkheims teoretiske grundforestilling skal i første omgang kun bemærkes, at den danske velfærdsstats udvikling alt i alt klart synes at bekræfte tesen om muligheden af samtidig vækst $i$ (organisk) solidaritet og individualitet - og dermed muligheden for velfærdsstaten som liberalt projekt (jf. Holmes, 1995).

\section{Aktivering som nyt paradigme}

Med aktiveringslinjen bliver den slags universelle ydelser, som tidligere udgjorde en velfærdspolitisk hovedløsning, i stedet betragtet som en væsentlig del af problemet, og alene denne "kopernikanske vending" gør det rimeligt at tale om et paradigmeskifte. Inspirationen stammer tydeligvis fra den forestilling om workfare frem for welfare, som på sin side udgør en hovedingrediens i den tredje vejs politik (Jordan, 1998; Rose, 1999). I den forbindelse er det vigtigt at mærke sig, at workfare ikke er ensbetydende med en neoliberalistisk minimalstats-strategi, der vil lade de frie markedskræfter råde, og fanden tage den sidste. Den er tværtimod primært knyttet til en kommunitaristisk bekymring for fællesskabets beståen (Mead, 1986, 1997; Etzioni, 1993) og en tilhørende tro på, at det ikke blot er statens ret, men også dens pligt at påtage sig ansvar for fællesskab og inklusion. Sekundært indeholder aktiveringsdiskursen dog også økonomisk-liberalistiske "noget for noget" ideer (Jespersen og Rasmussen, 1999; Nørskov Toke, 2002), og netop kombinationen af neoliberal "udbudsøkonomisk" tænkning og kommunitaristisk fællesskabsfilosofi synes karakteristisk for den nye tredje vej. For en mere generelt orienteret og grundig analyse af denne tilsyneladende naturstridige cocktail kan henvises til Rose, som plausibelt argumenterer for, hvordan begreber om human og social kapital udgør vigtige formidlende elementer, idet de introducerer "etho-politics into economics through the capitalization of morality in the service of national economic advantage" (Rose, 1999: 282). Her skal det i det følgende fremgå, hvordan blandingen viser sig i dansk aktiveringspolitik.

Et umiddelbart udtryk herfor er en karakteristisk dobbelthed i bekymringen for solidariteten. Bekymringen angår nemlig ikke kun velfærdsydelsernes hævdede (uheldige) virkninger på modtagersiden. Bekymringen drejer sig også om ydelsernes legitimitet på betalersiden, hvor problemet ligger i svækkelsen af de såkaldte "trækdyrs" fortsatte villighed til at skulle betale høje skatter for at underholde personer, der ikke yder noget til gengæld. Udtrykt af daværende socialminister Karen Jesper- 
sen kan "den solidariske holdning hurtigt skrumpe ind, hvis borgeme oplever, at deres surt tjente skattekroner går til nogle, der egentlig ikke har brug for dem, og som ikke selv gider at bidrage til fællesskabet" (Jespersen, 1999: 73).

Aktiveringsstrategiens basale antagelse er, at passiv forsørgelse virker såvel dekvalificerende som demotiverende. Den fjerner tilskyndelsen til at søge og påtage sig arbejde og resulterer dermed i marginalisering fra arbejdsmarkedet, hvilket så let medfører videregående social marginalisering og ultimativt leder til eksklusion af fællesskabet. Men svaret herpå er altså ikke laissez faire - laissez passer. Det er i stedet, hvad Giddens i The Third Way kalder "generative politikker" med henblik på opnåelse af såkaldt "positiv velfærd" (Giddens, 1998). Hvor den gamle velfærdsstat passiviserede og klientgjorde borgeme og svækkede det civile samfund, skal den tredje vejs velfærdsstat sikre, at den enkelte bliver i stand til at klare sig selv og dermed bidrage til fællesskabet. $\mathrm{Og}$ det centrale middel er altså pligten til at levere konkrete aktiveringsydelser til gengæld for den offentlige forsørgelse.

Nu kunne indvendes, at det ikke er noget nyt, at retten til at modtage dagpenge og kontanthjælp er modsvaret af pligter, og sammenlignet med hvad modtagere af understøttelse tidligere kunne komme ud for, kan dagens aktiveringskrav tage sig ret så uskyldige ud (Nørgaard, 1999). Dette skal selvfølgelig ikke benægtes, men i forhold til den skitserede udvikling i overførselssystemet forekommer det alligevel velbegrundet at tale ikke alene om kraftige stramninger (jf. Abrahamson og Oorschot, 2002: 16), men også om et markant brud. Ganske vist har der hele vejen igennem været tale om eksistensen af en pligt, nemlig rådighedspligten, altså pligten til at stå til rådighed for arbejdsmarkedet som forudsætning for at kunne modtage dagpenge og kontanthjælp. Men det afgørende er, at denne pligt til forskel fra aktiveringspligten er en generel pligt, som af den grund er helt uproblematisk i et liberalt medborgerskabsperspektiv. Det er en pligt til i givet fald at tage et job på samme forhandlede og kendte markedsvilkår, som er gældende for andre. Ligesom andre generelle pligter såsom skatte-, undervisnings- og væmepligt udtrykker rådighedspligten dermed en lighed i status (jf. Marshall). Den enkelte er forpligtet, som andre er forpligtet. I modsætning hertil medfører og institutionaliserer aktiveringen en forskel i status, hvor os bliver til dem og os. Pligten er en pligt til som modydelse for understøttelsen at arbejde, uddanne sig eller jobtræne på betingelser, der i sidste ende autoritativt bestemmes af den offentlige myndighed. Og det vil generelt sagt sige på dårligere og altså ulige løn- og arbejdsvilkår.

Sammenlignet med andre beskrivelser af aktiveringspolitikken kan denne karakteristik måske alligevel tage sig fortegnet ud. For eksempel fremhæver Torfing i sin analyse, at det i Danmark er lykkedes "to detach workfare from its neo-liberal 'origin' and to reformulate its content in accordance with the socio-political legacy in Denmark" (Torfing, 1999: 17). Hans tolkning lægger vægt på, at den danske succes med at bekæmpe arbejdsløsheden ikke reflekterer et stigende antal working poor, men den beror også på en anderledes vurdering af aktiveringskravene i forhold til den enkelte ledige. I den forbindelse er de såkaldte individuelle handlingsplaner af væsentlig betydning. Det er planer, der skal udarbejdes for hver enkelt ledig, og i overensstemmelse med de formulerede politiske intentioner understreger Torfing, hvordan planeme gør det muligt at målrette aktiviteter og krav, så de 
bliver meningsfulde for den enkelte, og endvidere påpeges, at "activation through participation in 'futile work-for-the-sake-of-working projects' is limited, as the law does not aim at repressing and punishing the unemployed" (Torfing, 1999: 18). Dette er umiddelbart korrekt, men kvalificerende må tilføjes, at det jo samtidigt åbenlyst fremgår, at aktivering ikke kun handler om gulerod, men også om stok. Således lægges ikke skjul på, at en nok så stor del af politikkens effekt skyldes den motivationsfaktor for de ledige, der ligger både $\mathrm{i}$ at skulle aktiveres og $\mathrm{i}$ udsigten til helt at miste indkomsten (Arbejdsministeriet, 2000).

I nogle tilfælde vil målretningen af indsatsen givetvis resultere i øget effektivitet, og desuden har flere evalueringsunders $\emptyset$ gelser vist, at et pænt flertal af de aktiverede er positive over for deres medvirken i aktiviteterne (Hansen, 2001). Alligevel forekommer det tvivlsomt at karakterisere aktiveringspolitikken $\mathrm{i}$ almindelighed og de individuelle handlingsplaner i særdeleshed som værende i overensstemmelse med den danske velfærdspolitiske arv. Generelt er politikken i strid med den liberale medborgerskabstradition, og handlingsplanen udgør som juridisk bindende dokument principielt og potentielt en vidtgående antastning af den enkeltes autonomi. Selve den ide, at det er opgaven og forpligtelsen for staten at indgå kontrakter med enkeltpersoner om noget, der så centralt angår deres hele tilværelse, repræsenterer en paternalisme, som synes fremmed for den danske liberale velfærdstradition (Nørskov Toke, 2002). Ganske vist kan paternalisme også nogle gange forsvares på liberalt grundlag, nemlig i situationer, hvor det drejer sig om personer, der for eksempel på grund af alder, sygdom eller afhængighed af stoffer, ikke er i besiddelse af autonomi. Men det kan der naturligvis kun helt undtagelsesvis være tale om, når det drejer sig om gruppen af ledige. Som påvist af Nørskov Toke er der derfor også i dansk socialpolitik tale om en bemærkelsesværdig diskrepans mellem på den ene side et område som tvangsbehandling af narkomaner, hvor lovgivningen har været meget tilbageholdende og stærkt præget af en angivelig frygt for paternalistiske ind- og overgreb, og på den anden side aktiveringslovgivningen, hvor en sådan frygt har været nærmest fraværende (Nørskov Toke, 2002).

Ud over at personer i aktivering tildeles en særlig og ringere status end personer på det ordinære arbejdsmarked, fordi de ikke er omfattet af de sædvanlige arbejdskontrakters overenskomstmæssige rettigheder - Marshall taler i den forbindelse om "kollektive civile rettigheder" - er det også en principiel væsentlig ændring, at der fra og med arbejdsmarkedsreformen fra 1994 ikke længere optjenes fornyet ret til dagpenge. Dette var tilfældet med de forudgående uddannelsesog jobtilbudsordninger, og som nævnt var det i kraft heraf, at der garanteredes mulighed for at bevare status som individuel indkomstmodtager. Denne garanti eksisterer ikke længere, idet dagpenge- plus såkaldt aktivperiode i dag er begrænset til i alt fire år. Derefter er der mulighed for at modtage bistandshjælp, men da den tildeles på grundlag af husstandsindkomsten, vil selv en moderat ægtefælleindtægt udelukke tildeling. På den måde kan (ufrivillig) privat forsørgelse igen siges at have vundet samfundsmæssig anerkendelse.' I forhold til kommunitaristiske forestillinger om det gunstige i stærke afhængighedsbånd til styrkelse af familiefællesskabet kan den ændring eventuelt ses som et fremskridt, men den synes vanskelig at bringe $\mathrm{i}$ harmoni med et liberalt ideal om lige medborgerskab. 
I debatten har det som et hovedargument mod de "passive" indkomstoverførsler været fremhævet, at de skaber afhængighed af staten og underminerer idealet om "at klare sig selv". Men bortset fra, at der jo fortsat er tale om statsafhængighed, så er det væsentlige i et medborgerskabsperspektiv ikke afhængighed som sådan. På utallige områder er det modeme menneske under alle omstændigheder afhængigt af statslige ydelser, rettigheder og reguleringer. Spørgsmålet drejer sig i stedet om forskellige typer af afhængighed. Og i medborgerskabsperspektivet er det betænkelige de former for afhængighed, der ikke fremgår af generelle lovbestemmelser, men som beror på bureaukratisk skøn og forgodtbefindende, og som derfor risikerer at svække borgerens autonomi og integritet og dermed ultimativt også at svække muligheden for at realisere de civile og politiske rettigheder. Inden for liberal politisk tænkning er muligheden for offentlig deltagelse i politik og meningsdannelse af central betydning (Holmes, 1995), men en sådan deltagelse forudsætter tilstedeværelse af den privatautonomi, som aktiveringssystemet potentielt svækker - er man afhængig på brødet af myndighedemes gode vilje, er det selvsagt et svagt udgangspunkt for eventuel kritisk politisk virksomhed; på principiel samme måde som det på grund af valgtryk var så som så med den lige valgret, før afstemningen kom til at foregå hemmeligt (Elklit, 1989).

Bortset fra sådanne principielt mulige direkte konsekvenser vil aktiveringen også mere indirekte kunne svække medborgerskabet. Dels ved at virke stigmatiserende - aktiverede er "svage" personer, der har brug for særlig indsats, herunder hjælp til at udvikle tilpas acceptable holdninger og personlige egenskaber (Carstens, 1998); og aktivering som opdragelse er selvfølgelig et mønstereksempel på kommunitaristisk legitimeret patemalisme. Dels ved at belønne og dermed eventuelt producere svaghed. Alle selektive, behovsprøvede ordninger rummer potentielt den "perversitet", at de tilskynder personen til at fremstille sig selv og sin situation i så dårligt et lys som muligt, idet det kan udløse ekstra fordele og goder; en mekanisme, der ikke er ukendt i dansk aktiveringssammenhæng (Mik-Meyer, 1999).

Mere generelt og sammenfattende kan forskellen mellem den gamle og den nye velfærdspolitiske tredjevej siges at bestå i to kategorialt forskellige begreber om fællesskab. Mens Marshalls citizenship - og det udtryk vælges eksplicit frem for community - er at forstå som et liberalt politisk-socialt fællesskab af borgere med lige rettigheder og pligter, da er det fællesskab, aktiveringspolitikken skal sikre, identisk med arbejdsfællesskabet; det fremgår - mekanisk - ved, at alle anerkender og opfylder normen om at arbejde. Aktivering betragtes netop ikke alene som et middel til at få flere i ordinært arbejde, men også som et selvstændigt mål, fordi den sørger for, "at mennesker kommer til at indgå i meningsfulde (arbejds)fællesskaber ... Det vil sige, at deltagelse i fællesskaber i denne sammenhæng er et mål i sig selv, fordi det anses at være godt for den enkelte - også selv om det ikke fører til selvforsørgelse" (Socialministeriet, 2000: 50-51.)

Som påpeget $\mathrm{i}$ flere analyser er en sådan kommunitaristisk argumentationsfigur udbredt i aktiveringsdiskursen (Jespersen og Rasmussen, 1998; Nørskov Toke, 2002). Med reference til Durkheim tyder det på, at der opereres med en mekanisk forestilling om solidaritet, hvor inklusion antages at bero på anerken- 
delse af fælles værdier og normer og med det at arbejde som topnorm par excellence. Defineres det samfundsmæssige fællesskab som (løn)arbejdsfællesskab, da bliver kravet om aktivering til en kategorisk fordring, dvs. en fordring, som ikke behøver begrundelse med henvisning til dens konsekvenser. Og det er da også karakteristisk, at overbevisningen om politikkens rigtighed og formålstjenlighed kun i ringe grad har ladet sig forstyrre af diverse undersøgelsers temmelig stærke problematisering af dens antagelser. Det gælder blandt andet den basale præmis om passiv forsørgelse som årsag til marginalisering. Nok er det klart blevet påvist, at ledighed generelt og langtidsledighed specielt er forbundet med en række sociale dårligdomme som misbrugsproblemer, øget risiko for familieopløsning, sygdom og tidlig død, osv. (Nygaard Christoffersen, 1996). Men der mangler overbevisende dokumentation for, at det typiske er, at ledigheden udgør årsagen og ikke virkningen; at for eksempel langvarig sygdom kan forårsage ledighed forekommer naturligvis mindst lige så plausibelt som det omvendte. Derimod foreligger der undersøgelser, som klart tyder på, at "passiv forsørgelse" ikke i omfattende grad resulterer i marginalisering (Goul Andersen, 1996, 2002; Lund Clement og Goul Andersen, 1999). Det overraskende synes snarere at være, i hvor høj grad også langvarigt ledige faktisk formår at opretholde den nonnale tilværelse og dagligdag med hensyn til blandt andet boform, kontakt med familie- og omgangskreds og deltagelse i diverse aktiviteter. Selv blandt førtidspensionister, der pr. definition har flere problemer end ledighed, viser det sig, at trivslen er høj. Ligeledes synes der ikke at være grundlag for omtalte frygt for en svindende solidaritet på samfundets "a-hold". I alle grupper har der været solid opbakning bag de økonomiske overførsler til de ledige (Goul Andersen, 1996).

Med hensyn til nedbringelsen af arbejdsløsheden op gennem 1990'erne er det som sagt almindeligt at tilskrive aktiveringspolitikken en væsentlig betydning. Det gøres ikke overraskende af de politisk ansvarlige for dens gennemførelse, men vurderingen finder også støtte fra forskerside, hvor det i en statusopgørelse for eksempel er hævdet, at udviklingen i 1990'eme er "svær at tolke uden at tillægge aktiveringspolitikken en væsentlig rolle" (Andersen, 2002: 11). Hvad denne vurdering nærmere bygger på fremgår ikke, men mig bekendt bekræftes den ikke af de foreliggende effektmålinger. En nylig oversigt over hidtidige unders $\varnothing$ gelser for både Holland og Danmark viser, at effekten har vist sig ret så begrænset og i nogle tilfælde endda negativ (Abrahamson og Oorschot, 2002). Ydermere sætter et panelstudie, der fulgte en gruppe ledige over en fireårig periode, kraftige spørgsmålstegn ved gyldigheden af den tilgrundliggende præmis om ledighedens strukturelle beskaffenhed. Således viste det sig, at de pågældende personers chance for formyet integration på arbejdsmarkedet kun marginalt om overhovedet hang sammen med det $\mathrm{i}$ henhold til denne præmis forventelige, nemlig forudgående ledighed, uddannelsesniveau og jobmotivation (Albrekt Larsen, 2002). Tillige er det til "miraklet" om nedbringelsen af den registrerede arbejdsløshed fra 349.000 i 1993 til 150.000 i 2000 svarende til 57 pct. værd at tilføje, at det totale antal offentligt forsørgede i samme periode kun faldt fra 1.034 .000 til 890.000 svarende til 14 pct. (Dansk Arbejdsgiverforening, 2001). Og endvidere, at beskæftigelsesraten i aldersgruppen 15-66 år var den samme i 1999 som i 1993, nemlig 73,5 pct. (CASA, 2000). 
Foruden ved hjælp af den type specifikke oplysninger og data lader aktiveringslinjens $\emptyset$ konomiske rationalitet sig eventuelt også problematisere mere generelt med henvisning til de forvridninger af markedsmekanismen, den strukturelt er forbundet med. Påvirkninger af incitamentsstrukturen med ikke tilsigtede konsekvenser til følge vil i kraft af ordningernes selektive karakter være mere reglen end undtagelsen. Det er således et erkendt problem, at deltagelse i aktiveringsarrangementer kan mindske i stedet for at øge deltagernes bestræbelser på at få et ordinært job. Men også på arbejdsgiversiden kan der "spekuleres" i den slags jobs "kunstige" var tidligere betegnelsen - som det såkaldt rummelige arbejdsmarked består af. Som illustrerende eksempel kan nævnes kommunernes brug af ordningen med såkaldt individuel jobtræning. Det er en ordning beregnet for ledige med problemer ud over ledigheden. Ikke desto mindre viser det sig, at den i stort omfang anvendes til gruppen af ledige uden den slags problemer. $\mathrm{Og}$ en væsentlig grund er givetvis, at det er en billig måde at få øget produktion af efterspurgte serviceydelser (Jepsen et al., 2002).

\section{Afsluttende: Den glemte organiske solidaritet}

Når kritiske oplysninger og data som ovenstående stort set ikke har foranlediget tvivl om aktiveringspolitikken som vejen frem, kan det nærliggende tages som udtryk for, at aktivering er blevet et mål i sig selv, og at diskursen om aktivering har etableret sig som dominerende diskurs eller paradigme. I den forbindelse har jeg søgt at argumentere for, at denne diskurs som noget centralt refererer til og prioriterer det samfundsmæssige fællesskab, og at den forstår dette fællesskab som et værdifællesskab omkring det at arbejde. På de præmisser er det ikke nødvendigt empirisk at undersøge, om passiv forsørgelse fører til marginalisering og social opløsning; det vides på forhånd. $\mathrm{Og}$ fordi der - jf. Durkheim - opereres på grundlag af en mekanisk præget forestilling om solidaritet, negligeres tilsvarende den mulige eksistens af en organisk solidaritet.

Til yderligere støtte for denne tolkning kan anføres, at den muliggør en forståelse af et grundlæggende paradoks i diskussionen om ledigheden, nemlig det forhold, at mens de problemer, arbejdsløsheden fører med sig, nok bekymrer, så bekymrer det tilsyneladende lige så meget, når arbejdsløsheden ikke resulterer i problemer. Således vakte det stærk furore, da en undersøgelse af arbejdsløses villighed til at påtage sig job kunne dokumentere, at omkring halvdelen ikke opfattede deres ledighedssituation som videre problematisk, ja, en del gav ligefrem udtryk for at nyde den (Goul Andersen, 1996: 182f.). Nogle var ikke interesseret $i$ et job "lige nu" og gjorde meget lidt for at få et. Andre ønskede i princippet et job, men heller ikke lige nu, og atter andre søgte kun job, fordi de var nødt til det. Hvis det antages, at solidariteten står og falder med fællesskab om værdier og normer $\mathrm{i}$ almindelighed og arbejdsnormen i særdeleshed, er dette naturligvis alarmerende oplysninger. Reaktionerme herpå fra opinionsdannere og beslutningstagere var da også stærke og præget af et tydeligt følelsesmæssigt engagement, og selve det faktum, at sådanne resultater kan virke så provokerende, tyder klart på en familielighed med den mekaniske solidaritet (jf. Loftager, 2001). Reaktionen skyldes ikke primært dokumenteret viden om de pågældende holdninger som funktionelt proble- 
matiske - arbejdsudbuddet var da heller ikke alvorligt forstyrret, og økonomien var generelt stærk. I stedet afspejler den, at dybtliggende og identitetsgivende værdier er blevet krænket. Derfor kan man i Durkheims sprog sige, at aktiveringens primære funktion ikke er restitutivt at genoprette en forstyrret tilstand. I stedet skal den sørge for, at den arbejdsløse soner den "forbrydelse", der består i at bryde normen om at udføre (betalt) arbejde og derigennem bidrage til fællesskabets opretholdelse.

Billedet tegner sig helt anderledes, hvis situationen i stedet betragtes med udgangspunkt i den organiske solidaritet. Da må først og fremmest som noget positivt noteres, at den mangeårige massearbejdsløshed ikke har fremkaldt nævneværdige tegn på kriser af økonomisk eller legitimitetsmæssig art og heller ikke har ført til omfattende marginalisering og social opløsning - solidaritet betegner ikke her primært aktørers subjektive holdninger og handlinger, men refererer til en objektiv samfundsmæssig tilstand. Tilsvarende må det betragtes som et gode snarere end et problem, at ledige kan udvise differentierede holdninger og tilskyndelser til det at søge og påtage sig job, når det samtidig viser sig, at arbejdsmarkedet generelt er velfungerende. Det må vurderes positivt, når universelle, passive (men altså ikke passiviserende) ordninger viser sig at give plads til individualitet og valgfrihed. På den måde respekteres modemitetens specifikke værdifællesskab.

I den dominerende (aktiverings)diskurs fremstilles den solidaritet, der består i $\emptyset$ konomiske overførsler som en sekunda-solidaritet, hvor man klarer sine forpligtelser over skattebilletten. Altså, for at solidaritet kan være ægte, må den indebære et personligt moralsk og emotionelt præget engagement og forpligtelse (jf. Juul, 2002) - man skal opleve sig selv som den gode giver, der tager hånd om de svage, som til gengæld må afkræves den rigtige indstilling. Såfremt det - som med det danske tilfælde - viser sig, at systemet af indkomstoverførsler bidrager til en tilsyneladende bæredygtig virkeliggørelse af et lige medborgerskab, vil man i perspektiv af Durkheim derimod betragte accepten af det høje skattetryk som et primært mål for en stærk organisk solidaritet. Det vil sige en solidaritet, der får samfundet til at hænge sammen og fungere, men som ikke forudsætter andet værdifællesskab end det, borgerrollen bygger på og realiserer.

Som anført har det i denne artikel været intentionen at perspektivere aktiveringslinjen i velfærdspolitikken som central del af tidens tredje vej ved at profilere den i forhold til den tredje vej, som tegnedes af den velfærdspolitiske udvikling forud for aktiveringsparadigmets gennembrud. Det afgørende nye er synet på indkomstoverførsler. Fra at udgøre en central del af svaret på den stadige udfordring om at forebygge marginaliserin , bliver sådanne ("passive") overførsler betragtet som en hovedårsag til marginalisering $\mathrm{og}$ eksklusion. Aktivering bliver da ikke alene et middel til at skabe flere ordinære jobs, men også et mål i sig selv som garant for fællesskabets opretholdelse. Imidlertid er den snævre sammenknytning af fællesskab og velfærdspolitik ikke noget nyt. Hovedsagen har netop været at påpege, at det nye er et skifte fra en politisk liberal forestilling om fællesskab, hvis karakter og logik er søgt fremstillet medhenvisning til Marshalls teori om et rettighedsbaseret medborgerskab og Durkheims teori om solidaritet, og til en kommunitaristisk præget forestilling, hvor fællesskabet antages at udspringe af fælles værdier og identiteter. 
Således beskrevet må det velfærdspolitiske sporskifte af flere grunde undre. For det første er der så vidt vides aldrig i debatten taget afstand fra det ideal om et lige medborgerskab à la Marshall, som aktiveringspolitikken udfordrer, hvorfor skiftets normative grundlag forekommer uklart. For det andet hviler politikken på tvivlsomme kausalpræmisser angående ledighedens overordnede karakter generelt og sammenhængen mellem passiv forsørgelse og marginalisering specielt. $\mathrm{Og}$ for det tredje forekommer fokuseringen på solidaritet som mekanisk solidaritet $\mathrm{i}$ det udviklede moderne samfund ret så overraskende.

Det har ikke her været anliggendet at forklare sporskiftet, men afslutningsvis kan skitseagtigt peges på nogle muligt relevante bud. Først og fremmest var der omkring 1990 uden tvivl tale om en ægte bekymring for det store og voksende antal mennesker på offentlig forsørgelse, og kombineret med de ændringer i det politisk-strategiske landskab, der fulgte med regeringsskiftet i 1993 (Green-Pedersen, 2000), frembragte det et stærkt handlingsberedskab og vilje til forandring. Samtidig var den tredje vej og diskussionen om welfare og workfare kommet på den internationale politiske dagsorden og kunne fungere som inspirationsgrundlag i en situation, hvor enigheden var stor om, at noget nyt var påkrævet. Endvidere var aktivering som princip allerede bragt på bane inden for socialpolitikken og delvist også på dagpengeområdet, jf. ovenfor. Når så aktiveringslinjen blev udbygget $\mathrm{og}$ befæstet op gennem 1990'erne skal det blandt andet ses på baggrund af en afgrænset succes med skærpede aktiveringskrav over for unge under 26 år, som efterfulgtes af en drastisk reduktion af ungdomsarbejdsløsheden.

I betragtning af de forskelligartede empiriske såvel som normative problematiseringer af aktiveringslinjen kan det alligevel være svært at forstå, så hurtigt og gennemgribende den er slået igennem. Måske det kan være udtryk for en mere generel tendens til, at (skiftende) ideer er kommet til at spille en større rolle i det senmoderne mere labile og uoverskuelige samfund - den (nye) tredje vej etablerer sig som den dominerende diskurs, der som sådan indeholder de konventionelle sandheder, de "nødvendige" politiske løsninger kan flyde af. I hvert fald - og måske som en delvist selvopfyldende profeti - vil det være i overensstemmelse med den måde, hvorpå dette samfund portrætteres i tidens populære sociologi. $\mathrm{Og}$ som Rose ikke så venligt bemærker, kan det se ud, som om "the practitioners of the Third Way do seem to try to interpret our present with the help of a sociological textbook or two" (Rose, 1999: 490).

\section{Note}

1. I hvilket omfang (ufrivillig) privat forsørgelse i praksis vil vokse, vil foruden den økonomiske konjunktur især afhænge af den måde, politikken implementeres på. Blandt andet kan kommunerne have stærke incitamenter til at sikre, at ledige bevarer retten til de overvejende statsligt finansierede arbejdsløshedsdagpenge. I artiklens sammenhæng er det centrale imidlertid nybruddet i den tilgrundliggende tænkning. 


\section{Litteratur}

Abrahamson, Peter and Wim van Oorschot (2002). The Dutch and Danish Miracles Revisited: Comparing the Role of Activation Policies Within Two Different Welfare Regimes, Paper, 2nd COST Action 15 Conference, Oslo, April.

Albrekt Larsen, Christian (2000). Det danske mirakel set fra jorden - en revurdering af grundlaget for aktiveringsstrategien, Speciale, Administrationsuddannelsen, Aalborg Universitet.

Albrekt Larsen, Christian (2002). "Challenging the Hegemonic Discourse of Structural Unemployment", CC WS Working Paper No. 2002-24, Aalborg University.

Andersen, Torben M. (2002). Socialforskning 2002:1.

Arbejdsministeriet (2000). Effekter af aktiveringsindsatsen, København: Arbejdsministeriet.

Bjøm, Ole (1998). Dengang Danmark blev moderne. Historien om den virkelige danske utopi, København: Gyldendal.

Carstens, Annette (1998). Aktivering - klientsamtaler og socialpolitik, København: Hans Reitzels Forlag.

CASA (2000). Social Årsrapport, København: Socialpolitisk Forlag.

Dansk Arbejdsgiverforening (2001). Arbejdsmarkedsrapport 2001. Tal og diagrammer, København: DA.

Durkheim, Émile (2000). Om den sociale arbejdsdeling, København: Hans Reitzels Forlag.

Elklit, Jørgen (1989). Fra åben til hemmelig afstemning, Århus: Politica.

Esping-Andersen, Gösta (1990). The Three Worlds of Welfare Capitalism, Oxford: Polity Press.

Etzioni, Amitai (1993). The Spirit of Community, London: Fontana Press.

Giddens, Anthony (1998). The Third Way: The Renewal of Social Democracy, Cambridge: Polity Press.

Goul Andersen, Jørgen (1996). "Marginalisation, Citizenship and the Economy: The Capacities of the Universalist Welfare State in Denmark", in Erik Oddvar Eriksen and Jøm Loftager (eds.), The Rationality of the Welfare State, Oslo: Scandinavian University Press.

Goul Andersen,Jørgen (2002). "Coping with Long-Term Unemployment: Economic Security, Labour Market Integration and Well-Being", International Journal of Social Welfare, Vol. 11, No. 3, pp. 178-190.

Green-Pedersen, Christoffer (2000). How Politics Still Matters, ph.d.-afhandling, Institut for Statskundskab, Aarhus Universitet.

Green-Pedersen, Christoffer, Kees van Kersbergen and Anton Hemerijck (2001). "Neo-Liberalism, the 'Third Way' or What? Recent Social Democratic Welfare Policies In Denmark and the Netherlands", Journal of European Public Policy, Vol. 8, No. 2, pp. 307-325.

Hansen, Henning (2001). Arbejde, aktivering og arbejdsløshed, Frederiksberg: Samfundslitteratur.

Ho, Marianne og Inge Stockholm Jørgensen (1999). Aktivering og medborgerskab. Fra passiv til aktiv social-og arbejdsmarkedspolitik - en kritisk analyse af Socialdemokratiets politiske kursskifte, specialeopgave, Institut for Statskundskab, Aarhus Universitet.

Holmes, Stephen (1995). Passions and Constraints, Chicago: Chicago University Press.

Jepsen, Maya Bak, Asbjøm Sonne Nørgaard og Janne Duch Vinderslev (2002). "Forskrifter, forhindringer og farlige fristelser: Aktivering af ledige i stat og kommuner", pp. 163-187 i Jens Blom-Hansen, Finn Bruun og Thomas Pallesen (red.), Kommunale Patologier, Århus: Systime.

Jespersen, Karen (1999). Opgør med den ny fattigdom, København: L\&R Fakta.

Jespersen, Stine Pilegaard og Stine Leth Rasmussen (1998). Fra velfardsstat til velfardssamfunden analyse af 90'ernes velfardsdebat, specialeopgave, Institut for Statskundskab, Aarhus Universitet.

Jordan, Bill (1998). The New Politics of Welfare, London: Sage.

Juul, Søren (2002). Modernitet, velfard og solidaritet, København: Hans Reitzels Forlag.

Knudsen, Tim (2001). Da demokrati blev til folkestyre, København: Akademisk Forlag.

Loftager, Jøm (2001). "Émile Durkheim: Borgerrollen og det multikulturelle", pp. 111-128 i Ove Korsgaard (red.), Poetisk demokrati, København: Gads Forlag. 
Loftager, Jørn. (1996). "Citizens Income - A New Welfare State Strategy?", pp. 134-149 in Erik Oddvar Eriksen and Jøm Loftager (eds.), The Rationality of the Welfare State, Oslo: Scandinavian University Press.

Lund Clement, Sanne og Jørgen Goul Andersen (1999). "Ny marginaliseringsunders $\emptyset$ gelse af førtidspensionister mv.", NYT, No. 2, pp.1-2, Institut for Økonomi, Politik og Forvaltning, Aalborg Universitet.

Madsen, Per Kongshøj (1999). Denmark: Flexibility, Security and Labour Market Success, Employment and Training Papers 53, Geneva: ILO.

Marshall, Thomas H. (1950). Citizenship and Social Class, Cambridge: Cambridge University Press.

Marshall, Thomas H. (1966). Class, Citizenship and the State, New York: Doubleday \& Company. Mead, Lawrence M. (1986). Beyond Entitlement, New York: The Free Press.

Mead, Lawrence M. (1997). "Welfare Employment" in Lawrence M. Mead (ed.), The New Paternalism, New York: The Free Press.

Mik-Meyer, Nanna (1999). Karlighed og opdragelse i socialaktiveringen, København: Gyldendal.

Nørgaard, Asbjørn Sonne (1999). "Viden og videnskab om velfærdsstaten: Er der én dansk velfærdsstat?", GRUS, 20. årgang, nr. 56/57, pp. 6-39.

Nørgaard, Asbjørm Sonne (2000). "Party Politics and the Organization of the Danish Welfare State, 1890-1920: The Bourgeois Roots of the Modern Welfare State", Scandinavian Political Studies, Vol. 23, No. 3, pp. 183-215.

Nørskov Toke, Karen (2002). Paternalisme i dansk socialpolitik - autonomi eller moralisme?, specialeopgave, Institut for Statskundskab, Aarhus Universitet.

Nygaard Christoffersen, Mogens (1996). Opvaekst med arbejdsløshed, København: Socialforskningsinstituttet, 96:14.

Olsen, Lars et al. (2002). Forsvar for fallesskabet, København: Fremad.

Rose, Nikolas (1999). "Inventiveness in politics", Economy and Society, Vol. 28, No. 3, pp. 467493.

Socialministeriet (2000). Socialpolitik som investering, Socialpolitisk Redegørelse 2000, København: Socialministeriet.

Torfing, Jacob (1999). "Workfare with Welfare: Recent Reforms of the Danish Welfare State", Journal of European Social Policy, Vol. 9, No. 1, pp. 5-28.

Turner, Bryan S. (ed.) (1993). Citizenship and Social Theory, London: Sage. 